\title{
ENCAPSULATED SOMATIC EMBRYOS AND ZYGOTIC EMBRYOS FOR OBTAINING ARTIFICIAL SEEDS OF RAULI-BEECH (Nothofagus alpina (Poepp. \& Endl.) Oerst.)
}

\author{
Priscila Cartes R. ${ }^{*}$, Hermes Castellanos B. ${ }^{2}$, Darcy Ríos L. ${ }^{1}$, Katia Sáez C. ${ }^{3}$, Scarlette Spierccolli H. ${ }^{1}$, \\ and Manuel Sánchez O. ${ }^{1}$
}

\begin{abstract}
Somatic and zygotic embryos from mature seeds of rauli-beech, Nothofagus alpina (Poepp. \& Endl.) Oerst., were encapsulated in different artificial endosperms in order to generate a cover that fulfills the function of nourishment and protection of the embryos, facilitating their later germination. The content of sodium alginate varied by $4 \%, 3 \%$, and $2 \%$, as did the immersion time in calcium chloride $\left(\mathrm{CaCl}_{2}\right)$, which acts as complexing agent. The artificial endosperm components of the Murashige and Skoog medium (MS) were added, supplemented with 0.5 $\mathrm{mg} \mathrm{L}^{-1}$ indolacetic acid (IAA), $0.5 \mathrm{mg} \mathrm{L}^{-1}$ naphthaleneacetic acid (NAA), $2 \mathrm{mg} \mathrm{L}^{-1}$ 6-benzylaminopurine (BAP) and $30 \mathrm{~g} \mathrm{~L}^{-1}$ sucrose. The germinative behaviors of encapsulated somatic and zygotic embryos were evaluated after $4 \mathrm{wk}$. Comparing the percentages of germination reached by encapsulated somatic and zygotic embryos it was observed that they had similar germinative behavior according to the type of encapsulation applied. However, zygotic embryos substantially exceeded the germination levels reached by somatic embryos, $100 \%$ vs. $45 \%$ respectively.
\end{abstract}

Key words: rauli-beech, somatic embryogenesis, synthetic seed, sodium alginate.

\section{INTRODUCTION}

The forestry sector has been one of the most dynamic in the Chilean economy since the 1970s, based mainly on plantating Pinus radita D. Don and Eucalyptus globulus Labill. This has led to a diminished importance of native forests in the national productive sector (INFORCORFO, 1997). However, the National Forest Recovery and Forestry Promotion Law has encouraged research, improvements in native species and the maintenance of forest ecosystems in order to strengthen this resource (CONAF, 2008).

The raulí-beech is a native Chilean species that has been recovering its ecological and economic importance in recent years after having suffered severe deterioration

\footnotetext{
${ }^{1}$ Universidad de Concepción, Facultad de Ciencias Forestales, Casilla 160-C, Concepción, Chile.

*Corresponding author (priscicartes@udec.cl).

${ }^{2}$ Universidad Juárez del Estado de Durango, Instituto de Silvicultura e Industria de la Madera, Boulevard del Guadiana 501 Fraccionamiento, Ciudad Universitaria C.P. 34120, Durango, México.

${ }^{3}$ Universidad de Concepción, Facultad de Ciencias Físicas y Matemáticas, Avda. Esteban Iturra s/n - Barrio Universitario, Concepción, Chile.

Received: 11 October 2007.

Accepted: 06 May 2008.
}

owing to indiscriminate extraction of the best individuals of forests, resulting in a decrease in the quality of the species today (Lara et al., 1996; Sánchez-Olate et al., 2000). The propagation of $N$. alpina by direct seeding raises difficulties because of the low tolerance of the species, which only grows successfully where mineral soils are exposed to light (Loewe et al., 1997; Donoso and Lara, 1999). As well, the low viability of the seeds, periodicity in seed production (high production in short cycles of 2 to 3 years) and insect attacks affect the development of this species (Burschel et al., 1976).

Techniques of micropropagation or in vitro cultivation have emerged as alternatives for species that do not have the property of producing viable seeds, that is, species that cannot germinate and develop adequately in their natural environment (González et al., 2004). Among the micropropagation techniques is somatic embryogenesis or the regeneration of embryos based on the vegetative tissue of $N$. alpina as an efficient technique that allows for the mass propagation of selected genotypes, for productive and conservation purposes (Castellanos et al., 2004). The success of this technique depends on the development of a series of processes that influence the genotype of the mother or donating explant and the concentration of exogenous growth regulators, which in adequate combinations would allow for obtaining a 
determinant embryogenic response for the production of somatic embryos (SE) (Guerra et al., 2001).

The SE can be immersed in a protective matrix constituting an artificial or synthetic seed, providing a convenient method for the propagation by cloning of elite plant varieties or species that are difficult to propagate in their natural environment (Fuji et al., 1987). The first indications of artificial seed propagation were reported in annual crops such as alfalfa (Medicago sativa $\mathrm{L}$.) and sugar cane (Saccharum spp.). Currently, systems of artificial seed production have progressed substantially in this area, the most advanced being in seeding under ex vitro or field conditions, obtaining high percentages of conversion to plants (Fuji et al., 1987; Nieves et al., 2003). However, the germination rates and the subsequent conversion to plants of SE of different woody species are still low, owing mainly to deficient and asynchronic maturation of the embryonic pole, which makes the terminal stages of the process difficult (Tapia et al., 1999; Castellanos et al., 2004).

Several researchers suggest that to control growth and facilitate the germination of SE, the synthetic endosperm can simulate an endosperm of sexual origin, containing one or several compounds such as: nutrients, growth regulators, anti-pathogens, herbicides, bio-controllers and bio-fertilizers, among others, with the aim of ensuring the conversion of the plant and its development in the field (Castillo et al., 1998; Kumar et al., 2004; Malabadi and Van Staden, 2005). The composition of the protective matrix should allow for the growth of the encapsulated embryo, providing mechanical resistance according to the available energy of the embryo, given that an excessively hard endosperm results in energy loss and weak or nil growth of the encapsulated ES (Jiménez and Quiala, 1998; González et al., 2004). The literature notes the use of different substances (agar, gelrite) to encapsulate ES, with the manipulation of the concentration of sodium alginate and the exposure time to the complexing agent calcium chloride reporting the best results of germination and conversion to plants in woody species (Patel et al., 2000; Maruyama et al., 2003; Utomo et al., 2008).

This study seeks to define the composition of synthetic endosperm, varying the sodium alginate content and exposure time to the complexing agent, with the goal of generating a synthetic endosperm that allows for the normal germination of encapsulated embryos. As well, the germinative behavior of somatic embryos and encapsulated zygotic of $N$. alpina are compared to determine the influence of the type of embryo on the germinative response.

\section{MATERIALS AND METHODS}

\section{Place of study}

The study was carried out in a vegetal tissue cultivation laboratory of the Forestry Sciences Faculty and the Biotechnology Center of the University of Concepción during 2006 and 2007 a period that covers the preparation of the initial material until the encapsulation and germination of the SE.

\section{Initial material}

The initial material was SE of $N$. alpina cultivated under axenic conditions obtained from proembriogenic mass (MPE) from the RaC01embryonic line (Raulíbeech, coyledonary explant, Clon 01). In accordance with established protocols for the species, based on embryogenic callus (Figure 1A) the continuous regeneration of MPE was generated MPEs (Figure 1B), from which the somatic embryos are isolated to encapsulate in a torpedocotyledonary state of development, with an approximate length of 3 to $4 \mathrm{~mm}$ (Figure 1C) (Castellanos et al., 2005).

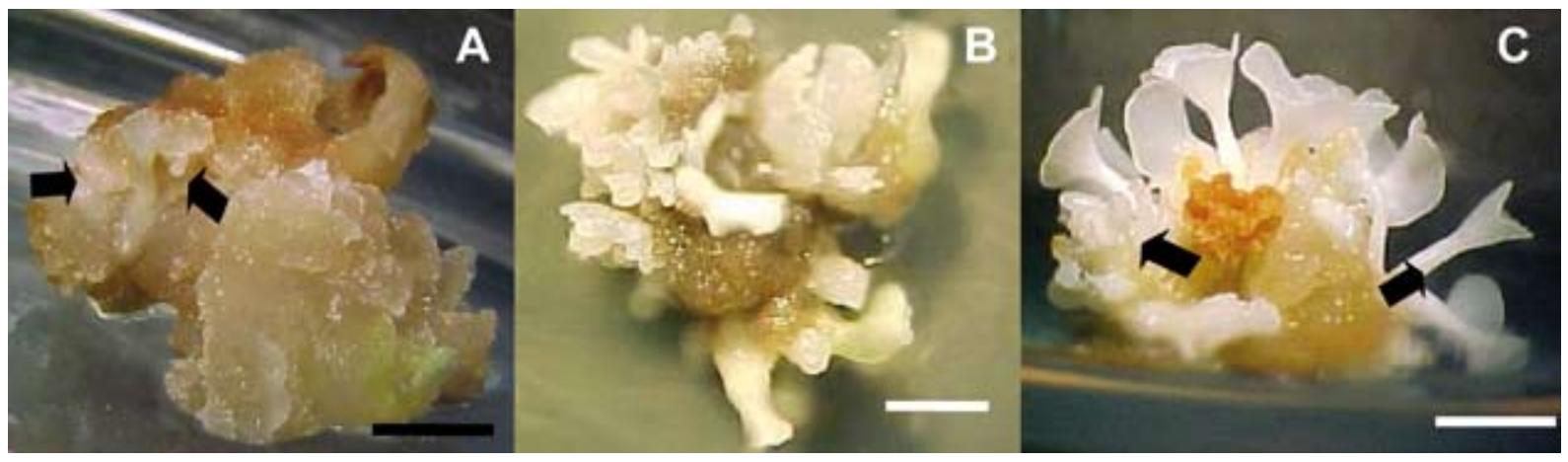

MPE: proembryogenic mass.

Figure 1. Somatic embryogenesis in Nothofagus alpina. A) Embryogenic callus after 16 wk; arrows indicate somatic embryo in cotyledonary stage (bar $=5 \mathrm{~mm})$; B) MPE with multiple embryogenic regions; C) MPE with at least 15 somatic embryos in cotyledonary and torpedo stages $(\mathrm{bar}=5 \mathrm{~mm})$. 


\section{Components of the artificial matrix}

The synthetic endosperm or artificial matrix was composed of minerals and vitamins from the MS culture medium (Murashige and Skoog, 1962) supplemented by $0.5 \mathrm{mg} \mathrm{L}^{-1}$ of indolacetic acid (IAA), $0.5 \mathrm{mg} \mathrm{L}^{-1}$ of naphthalene acetic acid (NAA), $2 \mathrm{mg} \mathrm{L}^{-1}$ of 6-benzyl aminopurine (BAP), $2 \mathrm{mg} \mathrm{L}^{-1}$ of Fe-EDTA and $30 \mathrm{~g} \mathrm{~L}^{-1}$ of sucrose. Depending on the encapsulation treatment applied, agar is replaced by sodium alginate at 4\% (E1), 3\% (E2) and 2\% (E3), according to Prewein and Wilhelm (2002), Ipekei and Gozukirmizi (2003) and Maruyama et al. (2003), respectively. The complexing agent of the capsules is applied through immersion in calcium chloride $\left(\mathrm{CaCl}_{2}\right)$ at different concentrations and determined time intervals (Table 1). Finally, they were washed in sterile water for 40 min.

Table 1. Components of the artificial endosperm used in the process of encapsulated somatic and zygotic embryos.

\begin{tabular}{lcrr}
\hline Treatments & Sodium alginate & $\mathbf{C a C l}_{2}$ & Time \\
\hline & $\%$ & $\mathbf{g ~ L}^{-1}$ & min \\
E1 & 4 & 15.0 & 10 \\
E2 & 3 & 5.5 & 30 \\
E3 & 2 & 14.0 & 30 \\
\hline
\end{tabular}

E1: type 1 encapsulated, sodium alginate at $4 \%$ and immersion in calcium chloride $15 \mathrm{~g} \mathrm{~L}^{-1}$ for $10 \mathrm{~min}$; E2: type 2 encapsulated, sodium at $3 \%$ and immersion in calcium chloride $5.5 \mathrm{~g} \mathrm{~L}^{-1}$ for $30 \mathrm{~min}$; E3: type 3 encapsulated, sodium at $2 \%$ and immersion in calcium chloride $14 \mathrm{~g} \mathrm{~L}^{-1}$ for $30 \mathrm{~min}$.

\section{Encapsulation of somatic embryos}

The somatic embryos isolated from the mass (Figure 2A) were submerged in a solution of sodium alginate (gel), according to the type of encapsulation applied, and subsequently suctioned through a micropipette (Figure $2 \mathrm{C})$ to provide a protective capsule. In order to seal the capsules, they were then submerged in a complexing solution of $\mathrm{de} \mathrm{CaCl}_{2}$ for a determined period of time (Table 1) followed by washing in sterile water for $40 \mathrm{~min}$ (Figure 2D). This process was carried out under aseptic conditions in a laminar flow chamber, laminar with prior sterilization of the material and culture medium (matrix). Finally, the artificial seeds were cultivated in a germination medium in Petri dishes with macro and micronutrient from the MS medium supplemented with $30 \mathrm{~g} \mathrm{~L}^{-1}$ of sucrose and $7 \mathrm{~g} \mathrm{~L}^{-1}$ of agar-agar. They were then left in the culture chamber at a temperature of $25 \pm 1{ }^{\circ} \mathrm{C}$ in complete darkness.

\section{Encapsulation of zygotic embryos}

The seeds of $N$. alpina were soaked for $48 \mathrm{~h}$ in running water. The seed surfaces were then disinfected by submerging the seeds in a solution of ethanol at $70 \%$ $(\mathrm{v} / \mathrm{v})$ for $5 \mathrm{~min}$, followed by washing in sterile water for $3 \mathrm{~min}$. Subsequently the seeds were placed in a commercial solution of sodium hypochlorite diluted to $50 \%(\mathrm{v} / \mathrm{v})$, following by three washings in sterile water for 3, 4 and $5 \mathrm{~min}$, respectively. This process was carried out under constant agitation in a laminar flow chamber. The protective tissue was then removed from the seeds,

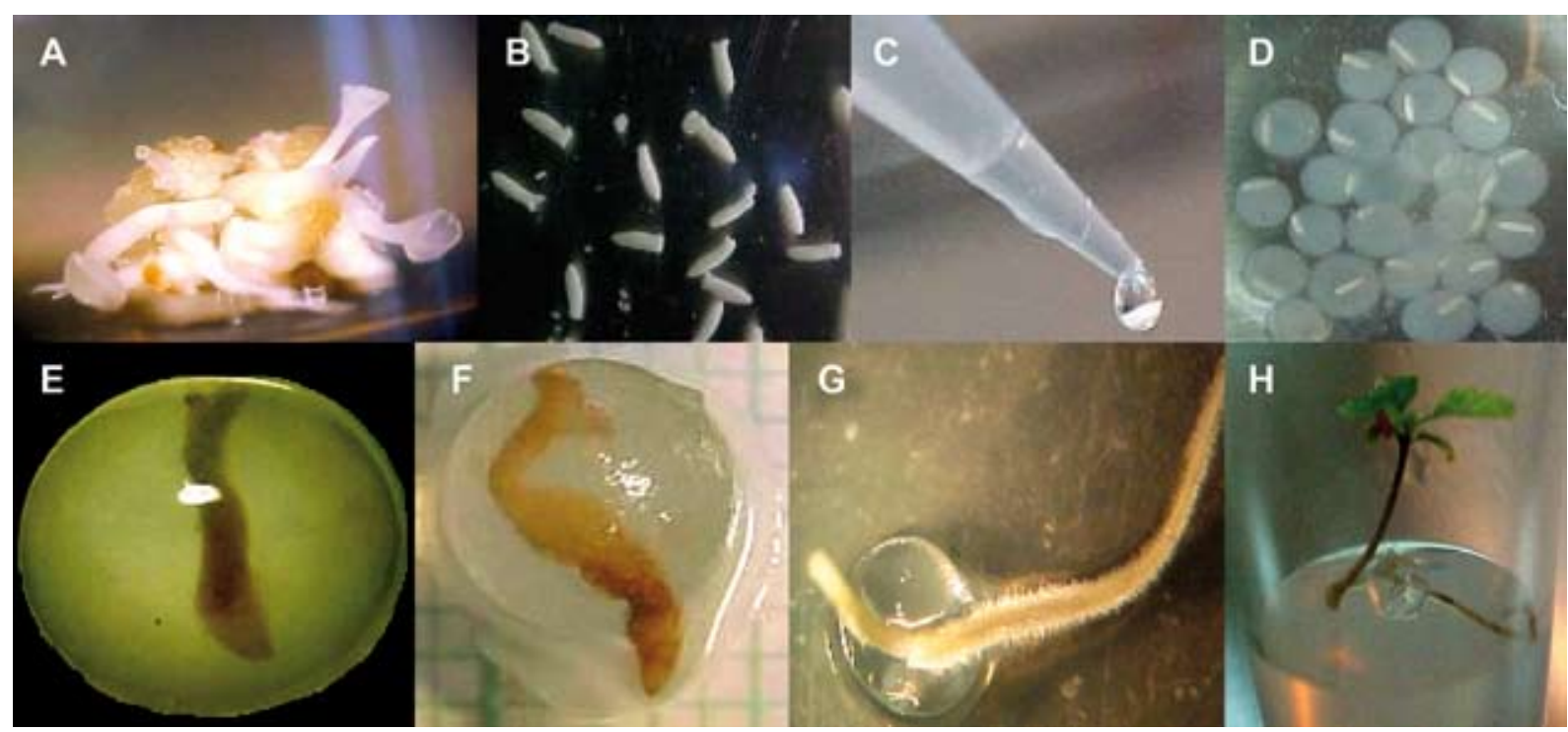

Figure 2. Encapsulation of somatic and zygotic embryos. A) Proembryogenic mass with somatic embryos in different development stages (bar $=2 \mathrm{~mm}$ ); B) zygotic embryos of Nothofagus alpina; C) encapsulate of somatic embryo through micropipette with sodium alginate; D) artificial seeds rinsed with sterile water for 40 min; E) survival of somatic embryo encapsulated after $21 \mathrm{~d}$; F) elongation of somatic embryo encapsulated in sodium alginate at $4 \%$; G) germination of zygotic embryo encapsulated in sodium alginate at $4 \%$ after $5 \mathrm{~d}$; $\mathrm{H}$ ) conversion of encapsulated zygotic embryo to plant after $14 \mathrm{~d}$. 
under a stereoscopic magnifier and with the aid of pincers and a sterilized scalpel. In this manner bare embryos were obtained ready to proceed to encapsulation (Figure 2B). The encapsulation process was the same as that applied to the somatic embryos (Table 1). Finally, the artificial seeds were cultured in a germination medium in Petri dishes with macro and micronutrients from the MS supplemented with $30 \mathrm{~g} \mathrm{~L}^{-1}$ of sucrose and $7 \mathrm{~g} \mathrm{~L}^{-1}$ of agar-agar, which were left in the culture chamber at a temperature of $25 \pm 1$ ${ }^{\circ} \mathrm{C}$ in darkness. Once the synthetic seeds germinated, they were transferred to the light, with a photoperiod of $16: 8$ (light:darkness) in the same growth chamber.

\section{Variables evaluated}

After 3 weeks in darkness, an evaluation was made of the percentage of encapsulated of somatic embryos and that presented elongation of the hypocotyl-root axis and of the survival rate. Subsequently, at 4 weeks the percentage of germination of encapsulated somatic embryos was evaluated. The criterion used to evaluate the germination of the encapsulated embryos was the emergence of the root from the artificial capsule.

The survival percentage of the zygotic embryos was evaluated and every four days the percentage of germination reached was evaluated, taking the emergence of the root from the capsule as a criterion.

\section{Experimental design}

The experimental design was oriented to determine the best germinative behavior of encapsulated somatic embryos in different artificial matrices. To do this three encapsulation procedures were evaluated (E1, E2 and E3), with three repetitions of each. The experimental unit was a Petri dishes with six artificial seeds, generating 18 seeds per encapsulate type.

The data obtained in percentages was submitted to arcsine transformation of the square root prior to the analysis. The effects of the treatments were evaluated using ANDEVA with a level of significance $(\alpha)$ of 0.05 . When there was a significant difference among treatments a minimum significant difference of means test (MSD) was carried out, for which the statistical program SAS (SAS Institute, 2002) was used.

To determine the behavior of the encapsulated zygotic and somatic embryos a completely random experimental design was used, with three treatments and four replications for each treatment. The experimental unit (Petri dish) was composed of six capsules generating a total of 24 artificial seeds per treatment.

\section{RESULTS AND DISCUSSION}

The levels of elongation of the hypocotyl-root axis and of survival of encapsulated somatic embryos at 21 days (Figure 2E and 2F) were higher by 70 and $90 \%$, respectively, in all the treatments applied (Table 2). As well, there were no significant differences in the different percentages of sodium alginate used and complexing time in $\mathrm{CaCl}_{2}$ among the aforementioned variables. However, a response was presented similar to what was obtained by authors such as Castillo et al. (1998), who observed a higher percentage of germination of encapsulated somatic embryos with increased sodium alginate content and reduced exposure time to $\mathrm{CaCl}_{2}$ (Prewein and Wilhelm, 2002; Malabadi and Van Staden, 2005). This is because high concentrations or excessive exposure of the embryos to the complexing agent $\left(\mathrm{CaCl}_{2}\right)$ results in more absorption and penetration of $\mathrm{CaCl}_{2}$ to the embryo, which can generate growth inhibition that is reflected in decrease in the germinative response and subsequent development in the field (Redenbaugh et al., 1986; Malabadi and Van Staden, 2005).

The importance of the high percentage of survival and germination obtained in the encapsulated zygotic embryos should be noted (Table 3). From these results it is clear that if the embryo reaches necessary vigor during the maturation phase, can break the mechanical resistance and lack of oxygen with increased sodium alginate content in the matrix, and thus the germinative response is not affected (Jiménez and Quiala, 1998). This can be extrapolated to somatic embryos, refining the maturation protocols to obtain better percentages of artificial seed germination (Nieves et al., 2001).

Table 2. Effect of different treatments of encapsulating applied to somatic embryos of Nothofagus alpina.

\begin{tabular}{lccc}
\hline Treatments & Survival & $\begin{array}{c}\text { Elongation of the } \\
\text { hypocotyl-root axis }\end{array}$ & Germination \\
\cline { 2 - 4 } E1 & & $\%$ & $45 \mathrm{a}$ \\
E2 & $99 \mathrm{a}$ & $83 \mathrm{a}$ & $31 \mathrm{a}$ \\
E3 & $97 \mathrm{a}$ & $79 \mathrm{a}$ & $35 \mathrm{a}$ \\
\hline
\end{tabular}

E1: type 1 encapsulated, sodium alginate at $4 \%$ and immersion in calcium chloride $15 \mathrm{~g} \mathrm{~L}^{-1}$ for $10 \mathrm{~min}$; E2: type 2 encapsulated, sodium at $3 \%$ and immersion in calcium chloride 5,5 $\mathrm{g} \mathrm{L}^{-1}$ for $30 \mathrm{~min}$; E3: type 3 encapsulated, sodium at $2 \%$ and immersion in calcium chloride $14 \mathrm{~g} \mathrm{~L}^{-1}$ for $30 \mathrm{~min}$ Means following by the same letter in the columns do not differ significantly among themselves according to the Minimum Significant Difference test $(\mathrm{P}>0,1)$. 
Table 3. Effect of different treatments of encapsulating applied to zygotic embryos of Nothofagus alpina.

\begin{tabular}{lcr}
\hline Treatments & Survival & Germination \\
\cline { 2 - 3 } E1 & $100 \mathrm{a}$ & $95.8 \mathrm{a}$ \\
E2 & $100 \mathrm{a}$ & $100.0 \mathrm{a}$ \\
E3 & $100 \mathrm{a}$ & $95.8 \mathrm{a}$ \\
\hline
\end{tabular}

E1: type 1 encapsulated, sodium alginate at $4 \%$ and immersion in calcium chloride $15 \mathrm{~g} \mathrm{~L}^{-1}$ for $10 \mathrm{~min}$; E2: type 2 encapsulated, sodium at $3 \%$ and immersion in calcium chloride $5.5 \mathrm{~g} \mathrm{~L}^{-1}$ for $30 \mathrm{~min}$; E3: type 3 encapsulated, sodium at $2 \%$ and immersion in calcium chloride $14 \mathrm{~g} \mathrm{~L}^{-1}$ for $30 \mathrm{~min}$

Means following by the same letter in the columns do not differ significantly among themselves according to the Minimum Significant Difference test $(\mathrm{P}>0.1)$.

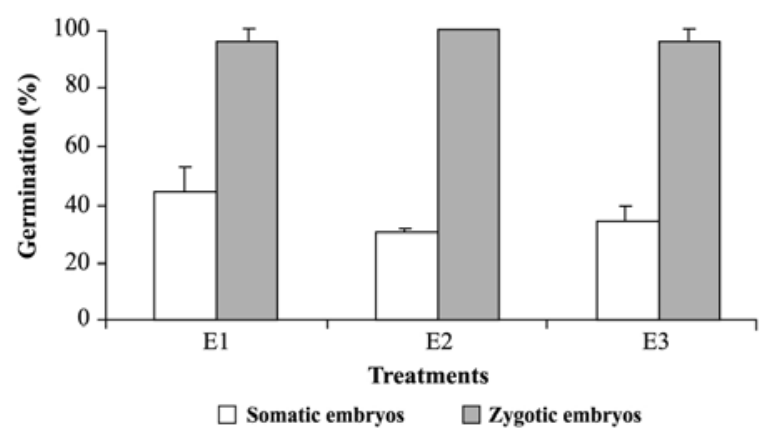

E1: type 1 encapsulated, sodium alginate at $4 \%$ and immersion in calcium chloride $15 \mathrm{~g} \mathrm{~L}^{-1}$ for $10 \mathrm{~min}$; E2: type 2 encapsulated, sodium at $3 \%$ and immersion in calcium chloride $5.5 \mathrm{~g} \mathrm{~L}^{-1}$ for 30 min; E3: type 3 encapsulated, sodium at $2 \%$ and immersion in calcium chloride $14 \mathrm{~g} \mathrm{~L}^{-1}$ for $30 \mathrm{~min}$.

Figure 3. Comparison of germination percentage of encapsulated zygotic embryos vs. encapsulated somatic embryos.

Comparing the germinative behavior of encapsulated somatic and zygotic embryos it can be observed that both types of embryos have similar behavior according to the encapsulation treatment applied (E1, E2 and E3). However, the zygotic embryos strongly surpassed the germination levels ( $100 \%$ for E2) reached by the somatic embryos (44\% for E1) (Figure 3). Some authors suggest that the germination of ES is affected by the degree of vigor or maturity of the embryos at the moment of being encapsulated (Gómez, 1998; Nieves et al., 2001), given that the mechanical resistance that an excessively hard encapsulation can result in a major part of the available energy being utilized in breaking the synthetic endosperm (Jiménez and Quiala, 1998).

It is important to point out that the zygotic embryos germinated at 4 days of cultivation (Figure 2G), achieving the conversion to plants (Figure 2H), while the somatic embryos germinated at approximately 4 weeks and in an irregular manner, manifesting a lack of maturity and asynchrony in the development of these embryos (Castellanos et al., 2004). However, refining the encapsulation process for somatic embryos, with the goal of improving the percentages of germination and subsequent conversion to plants, can mean the generation of a cloning product with the potential to outperform seeds of sexual origin (Tapia et al., 1999; Nieves et al., 2001).

\section{CONCLUSIONS}

The encapsulation procedure can be applied to both types of embryos of N. alpina, somatic and zygotic, allowing for the normal germination of embryos.

There were significant differences in the percentage of germination reached for somatic embryos and zygotes according to the percentage of sodium alginate $(2 \%, 3 \%$ and $4 \%$ ) and the exposure time to the calcium chloride agent.

The higher levels of germination were reached by the zygotic embryos in comparison to the somatic embryos, owing mainly to the lack of maturity and asynchrony of the embryoids.

\section{RESUMEN}

Encapsulado de embriones somáticos y embriones cigóticos para obtención de semillas artificiales de raulí (Nothofagus alpina (Poepp. \& Endl.) Oerst.). Embriones somáticos y cigóticos provenientes de semillas maduras de raulí, Nothofagus alpina (Poepp. \& Endl.) Oerst., se encapsularon en diferentes endospermas sintéticos con el fin de generar una cubierta que cumpla la función de nutrir y proteger al embrión para facilitar su posterior germinación. Se varió el contenido de alginato de sodio al $4 \%, 3 \%$ y $2 \%$ y el tiempo de inmersión en cloruro de calcio $\left(\mathrm{CaCl}_{2}\right)$, el que actúa como agente acomplejante. Además, a la matriz artificial se adicionaron componentes del medio Murashige y Skoog (MS) suplementado con: $0,5 \mathrm{mg} \mathrm{L}^{-1}$ de indolacetic acid (IAA), $0,5 \mathrm{mg} \mathrm{L}^{-1}$ de ácido naftalenacético (NAA), $2 \mathrm{mg} \mathrm{L}^{-1}$ de 6-bencilaminopurina (BAP) y $30 \mathrm{~g} \mathrm{~L}^{-1}$ de sacarosa. Al cabo de 4 semanas el porcentaje de germinación de los embriones somáticos y cigóticos encapsulados tuvieron similar comportamiento germinativo según el tipo de encapsulado aplicado. Sin embargo, los embriones cigóticos superaron ampliamente los niveles de germinación alcanzados por los embriones somáticos, $100 \%$ vs. $45 \%$, respectivamente.

Palabras clave: raulí, embriogénesis somática, semilla sintética, alginato de sodio. 


\section{LITERATURE CITED}

Burschel, P., C. Gallegos, O. Martínez, y W. Moll. 1976. Composición y dinámica regenerativa de un bosque virgen mixto de raulí y coigüe. Universidad Austral de Chile, Valdivia. Bosques (Chile) 1:55-74.

Castellanos, H., M. Sánchez-Olate, y D. Ríos. 2004. Embriogénesis somática recurrente en raulí (Nothofagus alpina (Poepp. et Endl.) Oerst.). 36 p. In Segundo Congreso Chileno de Ciencias Forestales, Valdivia, Chile. 10-12 de noviembre. Universidad Austral de Chile, Valdivia, Chile.

Castellanos, H., M. Sánchez-Olate, y D. Ríos. 2005. La embriogénesis somática como alternativa para la regeneración in vitro de raulí y roble. p. 59-74. In B. Gutiérrez et al. (eds.) Clonación de raulí: estado actual y perspectivas. Instituto Forestal (INFOR), Centro de Producción y Experimentación Forestal (CEFOR S.A.), Universidad Austral de Chile, Fondo de Desarrollo e Innovación y Corporación de Fomento de la Producción (FDI-CORFO), Concepción, Chile.

Castillo, B., M.A.L. Smith, and U.L. Yadava. 1998. Plant regeneration from encapsulated somatic embryos of Carica papaya L. Plant Cell Rep. 17:172-176.

CONAF. 2008. Ley de Recuperación del Bosque Nativo y Fomento Forestal. Corporación Nacional Forestal (CONAF), Santiago, Chile. Disponible en http://www. conaf.cl/ (Leído el 10 de julio del 2008).

Donoso, C., y A. Lara. 1999. Silvicultura de los bosques nativos de Chile. 420 p. Editorial Universitaria, Santiago, Chile.

Fuji, J.A., D.T. Slade, K. Redenbaugh, and K.A. Walker. 1987. Artificial seeds for plant propagation. Trends Biotechnol. 5:335-339.

Gómez, R. 1998. Embriogénesis somática. p. 57-79. In J.N. Pérez (ed.) Propagación y mejora genética de plantas por biotecnología. Instituto de Biotecnología de las Plantas, Santa Clara, Villa Clara, Cuba.

González, O., J. Silva, y A. Espinosa. 2004. Semilla artificial: una solución en la biodiversidad mundial. p. 17-22. In E. Galante (ed.) Cuadernos de Biodiversidad $\mathrm{N}^{\mathrm{o}}$ 15. Centro Iberoamericano de Biodiversidad (CIBIO), Universidad de Alicante, Alicante. España.

Guerra, M.P., L.L. Dal Vesco, J.P.H. Ducroquet, R.O. Nodari, and M.S. Reis. 2001. Somatic embryogenesis in Feijoa sellowiana: genotype response, auxinic shock and synthetic seeds. Rev. Bras. Fisiol. Veg. 13:117-128.

INFOR-CORFO. 1997. Boletín Estadístico. Estadísticas Forestales. Instituto Forestal (INFOR) y Corporación de Fomento de la Producción (CORFO), Santiago, Chile.
Ipekei, Z., and N. Gozukirmizi. 2003. Cell biology and morphogenesis. Direct somatic embryogenesis and synthetic seed production from Paulownia elongata. Plant Cell Rep. 22:16-24.

Jiménez, E., y E. Quiala. 1998. Semilla artificial. p. 225240. In J.N. Pérez (ed.) Propagación y mejora genética de plantas por biotecnología. Instituto de Biotecnología de las Plantas, Santa Clara, Villa Clara, Cuba.

Kumar, M., V. Vakeswaran, and V. Krishnasamy. 2004. Enhancement of synthetic seed conversion to seedlings in hybrid rice. Plant Cell Tiss. Organ Cult. 81:97-100.

Lara, A., C. Donoso, y J.C. Aravena. 1996. La conservación del bosque nativo de Chile: Problemas y desafíos. p. 335-361. In Armesto, J.J., C. Villagrán, y M.K. Arroyo (eds.) Ecología de los bosques nativos de Chile. Comité de Publicaciones Científicas, Vicerrectoría Académica, Universidad de Chile, Santiago, Chile.

Loewe, V., M. Toral, G. Freitte, M. Camelio, M. Mery, C. López, y E. Urquieta. 1997. Monografía del raulí. Nothofagus alpina. Corporación Nacional Forestal (CONAF), Instituto Forestal (INFOR) y Fondo de Innovación Agraria (FIA), Santiago, Chile.

Malabadi R., and J. Van Staden. 2005. Storability and germination of sodium alginate encapsulated somatic embryos derived from the vegetative shoot apices of mature Pinus patula trees. Plant Cell Tiss. Organ Cult. 82:259-265.

Maruyama, E., Y. Hosoi, and K. Ishii. 2003. Somatic embryo culture for propagation, artificial seed production, and conservation of sawara cypress (Chamaecyparis pisifera Sib. et Zucc.). J. For. Res. 8:1-8.

Murashige, T., and F. Skoog. 1962. A revised medium for rapid growth and bioassays with tobacco tissue cultures. Physiol. Plant. 15:473-497.

Nieves, N., J. Lorenzo, M. Blanco, J. González, R. Tapia, y A. González. 2001. Composición de un endospermo artificial para embriones de mandarina "Cleopatra" (Citrus reshni Hort es Tan). Rev. Fac. Agron. (Maracay) 27:11-15.

Nieves, N., Y. Zambrano, R. Tapia, M. Cid, D. Pina, and R. Castillo. 2003. Field performance of artificial seedderived sugarcane plants. Plant Cell Tiss. Organ Cult. 75:279-282.

Patel, A.V., I. Pusch, G. Mix-Wagner, and K.D. Vorlop. 2000. A novel encapsulation technique for the production of artificial seeds. Plant Cell Rep. 19:868874.

Prewein, C., and E. Wilhelm. 2002. Plant regeneration from encapsulated somatic embryos of pedunculate oak (Quercus robur L.). In Vitro Cell. Dev.-Pl. 39:613617. 
Redenbaugh, K., B.D. Paasch, J.W. Nichol, M.E. Kossler, P.R Viss, and K.A Walker. 1986. Somatic seeds: encapsulation of asexual plant embryos. Bio-Technol. 4:797-801.

Sánchez-Olate, M., D. Ríos, y L. Mardones. 2000. Micropropagación de algunas leñosas nativas. $51 \mathrm{p}$. Universidad de Concepción, Facultad de Ciencias Forestales, Departamento de Silvicultura, Concepción, Chile.

SAS Institute. 2002. SAS ${ }^{\circledR}$ User's guide: Statistics. Version 9.0. SAS Institute, Cary, North Carolina, USA.
Tapia, R., R. Castillo, N. Nieves, M. Blanco, J. Gonzáles, M. Sánchez, y Y. Rodríguez. 1999. Inducción, maduración y encapsulación de embriones somáticos de caña de azúcar (Saccharum sp.) var. Cp 5243. Biotecnología Aplicada 16(1):20-23.

Utomo, H.S., I. Wenefrida, M.M. Meche, and J.L. Nash. 2008. Synthetic seed as a potential direct delivery system of mass produced somatic embryos in the coastal marsh plant smooth cordgrass (Spartina alterniflora). Plant Cell Tiss. Organ Cult. 92:281291. 